\title{
IS IT FORBIDDEN THE WOOD USE OF Araucaria angustifolia? AN ANALYSIS ON THE CURRENT LEGAL BUDGET
}

\author{
Rozane de Loyola Eisfeld ${ }^{1}$, Julio Eduardo Arce ${ }^{2}$, Carlos Roberto Sanquetta ${ }^{3}$, Evaldo Muñoz Braz ${ }^{4}$ \\ ${ }^{1} \mathrm{PhD}$ Student in Forest Sciences, Forest Engineer, UFPR, Curitiba, PR, Brazil - rozaneloyolaeisfeld@ hotmail.com \\ ${ }^{2} \mathrm{PhD}$ in Forest Sciences, Forest Engineer, UFPR, Curitiba, PR, Brazil - jarce@ufpr.br \\ ${ }^{3}$ Doctor of Forest Sciences, Forest Engineer, UFPR, Curitiba, PR, Brazil - sanquetta@ufpr.br \\ ${ }^{4} \mathrm{PhD}$ in Forest Sciences, Researcher at Embrapa Forests, Forest Engineer, UFPR, Curitiba, PR, Brazil - evaldo.braz@embrapa.br
}

Received for publication: 20/06/2018 - Accepted for publication: 29/04/2019

\begin{abstract}
Resumo
É proibido o uso madeireiro da Araucaria angustifolia? Uma análise sobre o arcabouço jurídico atual. Este trabalho teve como objetivo analisar o arcabouço jurídico sobre um tema bastante complexo no setor florestal: o uso de uma espécie ameaçada de extinção, neste caso a araucária. Após anos de intenso extrativismo madeireiro, vinculada ao crescimento econômico do País, edita-se, a partir da década de 1960, uma gama de normativas orientadas ao controle do uso das florestas por meio de leis rigorosas e expansão da burocracia ambiental. Em 2014, via Portaria MMA 443, inclui-se a araucária na categoria em perigo, restringindo qualquer aproveitamento madeireiro à espécie, inclusive sob manejo florestal. Sua justificativa de enquadramento advém de redução populacional, desmatamento e exploração madeireira. Quanto às justificativas do seu enquadramento, salienta-se a não divulgação de dados oficiais de área remanescente e número de indivíduos, temas de obrigação do Estado. A Portaria 443 colide com a Lei Florestal brasileira ao retirar direitos, neste caso o manejo florestal, não estabelecidos na Lei nº 12.651 de 2012. Também descumpre a Lei Complementar 140 que estabelece laudos e estudos técnico-científicos para enquadramento das espécies da lista. Também não cumpre as etapas exigidas no artigo $5^{\circ}$ da Portaria MMA 43, a qual é precedente a Portaria 443. Mediante a análise das normativas, referentes à espécie araucária, quanto sua utilização comercial: não existe lei que proíba o uso, via manejo e plantio; o que existe são portarias e resoluções. Quem se acha no direito messiânico de proibir o corte da espécie, subsidia-se em portarias e resoluções. E quem se acha no direito de cortar, desconhece a legislação.

Palavras-chave: legislação florestal; produção florestal; espécie ameaçada de extinção.
\end{abstract}

\begin{abstract}
The objective of this work was to analyze the legal arrangements on a very complex theme in the forest sector: the use of a species threatened with extinction, araucaria. After years of intense deforestation, linked to the country's economic growth, after 1960 decade, it was edited an array of regulations aimed to control the forest use through strict laws and expansion of the environmental bureaucracy. In 2014, MMA Decree 443, araucaria was included in the danger category, restricting any timber use, including the ones gathered under forest management. The justification for this inclusion comes from the population reduction, deforestation and logging. Regarding the justification of its inclusion, it is important to note the non-disclosure of official data, an obligation of the State, on the remaining area and number of individuals. Decree 443 collides with the Brazilian forest low removing rights, as forest management, not established by Law number 12.651 of 2012. It also defies the Complementary Law 140 which establishes reports and technical-scientific studies for framing the listed species. Nor does it comply with the steps required in article $5^{\circ}$ MMA Decree 43 , which precedes Decree 443. By analyzing the regulations regarding the araucaria and its commercial use: there is no law prohibiting the use, through management and planting; what exists are Decrees and resolutions. Whoever is in the messianic right to forbid the cutting of the species, subsidizes itself in Decrees and resolutions. Moreover, who believes they have the right to cut it, is not aware of the legislation.

Keyword: forest legislation; forest production; endangered species.
\end{abstract}

\section{INTRODUCTION}

The idea of protecting representative areas of the natural ecosystems of a given environment in the Brazilian territory comes from the creation of the 1934 Forest Code. However, despite this already having preservationist characteristics and the recognized importance of forests, coupled with the strong pressures of national and international environmental movements, the Mixed Ombrophilous Forest (FOM) phytophysiognomy, a naturally occurring area of Araucaria, was being devastated. This phytophysiognomy, also known as Araucaria Forest, is included in the Atlantic Forest Biome, according to Federal Law number 11,428 of December 22, 2006. According to the Paraná Forest Research Foundation (FUPEF, 2001), the areas of native forest remnants F.O.M. (Mixed Ombrophilous Forest) total 2.5 million hectares (30\% of the original) and advanced forests only $0.8 \%$ of

FLORESTA, Curitiba, PR, v. 50, n. 1, p. 971 - 982, jan/mar 2020

Eisfeld, R. L. et.al.

ISSN eletrônico 1982-4688 
the original area. The process of devastation peaked in the second half of the last century, with the banner of the opening of new agricultural frontiers, the creation of new jobs and social development.

From 1960 and in order to curb the deforestation that occurred in the country, a wide range of norms was created through laws, decrees, decree laws, normative instructions, Decrees and resolutions. Such measures, coupled with increased enforcement, have reduced deforestation; however, they have also reduced an important economic activity in the country that does not imply land conversion or significant negative social and environmental impacts: forest management of native timber species. Management is a technique of logging that respects the support mechanisms of the ecosystem under management (BRAZIL, 2012). This technique is widely spread in many countries, applied for centuries, among which: Germany, Canada, United States, Finland, Hungary, Costa Rica, Colombia, among others; However, in Brazil, the technique is still viewed with restrictions.

Specifically in the State of Paraná, since the publication of Resolution number 278 of May 24, 2001 (BRAZIL, 2001), any commercial use of threatened species in areas of natural populations has been forbidden, with the suspension of cutting or suppression endangered species until technical criteria were established. Through this one-year rule, renewable for one more year, the process of suspension of timber forest management activities in the Atlantic Forest biome begins.

As for Araucaria, the suspension of logging of the remnants, under forest management, also dates from 2001. The reduction in intensive exploitation of the species, in the form of clearcutting, is earlier initiated, by prohibiting the slaughter of adult individuals. pine cone carriers in 1976 (BRAZIL, 1976).

Currently, there are 17 years of suspension of management plans, logging of the species; However, the picture remains worrying: reduction of the natural area, reduction of the planted area, absence of natural regeneration of the species in the remnants of remaining areas and divorce between the producer and the species.

The truth for this species can be summed up as: "much is discussed, little is resolved." And in this situation of uncertainty about the direction of the species, current legislation seems to be largely responsible for its critical scenario. But is legislation really the big villain? Thus, this paper aims to rescue this discussion by analyzing the legal framework unique to the Araucaria species (Araucaria angustifolia (Bertol.) Kuntze.).

\section{MATERIAL AND METHODS}

The method used for the research was the diagnostic analysis, which consisted of surveying the influence of environmental and forest legislation related to the Araucaria species. The object of study focused on forest management and planting activities in the State of Paraná, through an interrelation between forest economic activities and the respective legislation.

Regarding the nature, this research was considered applied, which seeks the practical solution of the problem, through technical and legal justifications directed to the understanding of forest management in the State of Paraná, involving social, economic and environmental interests. Regarding the approach to the problem, it was a qualitative research, in which there is no way to translate its results into numbers, besides not requiring the use of statistical methods and techniques. The results were generated by the inductive analysis of the main focuses of the problem approach, that is, on the theme of reducing the area of the forest with Araucaria and on the commercial exclusion of timber from the species. Regarding its objectives, this research was exploratory, in which the knowledge of the technical and legal questions about the Araucaria species involves the bibliographic survey of legal norms and technical works that provide subsidies for the understanding, understanding and analysis of the studied subject. Regarding the technical procedures, it was a bibliographic and documentary research, elaborated from the survey and study of the legal arrangement and the analysis of scientific articles, books and other published works that addressed the analyzed theme. Therefore, we proceeded to a bibliographic survey, as well as the analysis of the main Decrees, laws, resolutions and decrees related to the theme in question.

The reserach concludes with a discussion of the legislative elements discussed above, seeking to meet the initial objectives proposed regarding the legislation and the legality of the use of the species, under management or planting, in the State of Paraná.

\section{RESULTS}

The analysis now performed sought to discuss about the Brazilian legal system, which is the forest legislation, focusing on the norms referring to the object of study, the Araucaria species.

The legal framework involving the use of native forests in Brazil is extremely extensive. Among the normative, the main current legislations, referring to the subject in question, are analyzed in the subsequent items. 


\section{Brazilian Constitution of 1988}

The current Brazilian Constitution, promulgated in 1988, Chapter VI, discusses the environment, in Article 225, which states that "everyone has the right to an ecologically balanced environment, a common use of the people and essential to a healthy quality of life., imposing on the Public Power and the collective the duty to defend and preserve it for present and future generations "(BRASIL, 1988).

A major diploma of the Brazilian legal system, the 1988 edition of the Brazilian Constitution represented a major breakthrough in environmental matters as, for the first time in Brazilian constitutional legislative history, a chapter is devoted to protecting the environment Pires (2006). The Government is responsible for several tasks aimed at ensuring the effectiveness of the right to the ecologically balanced environment addressed in the main section of the article.

The Constitution innovates by introducing the term "ecologically balanced". According to Odum (1977) ecology derives from the Greek root: oikos, which means "house". Thus, literally, ecology is the study of "houses," or by extension, "environments." It is the interaction of living beings with the environment they inhabit. Therefore, Article 225 strives for a balanced environment in the economic, social and environmental sense.

The first paragraph of Article 225 lists measures that the Government must take to ensure the effectiveness of the right recognized in the caput. Item I refers to the preservation and restoration of essential ecological processes. The second part of the section refers to the promotion of ecological management of species and ecosystems, an issue that has an umbilical relationship with this study. Thus, the largest document that governs the country's legal system, the Brazilian Constitution of 1988, innovative in its discussion of the environment in its article 225, item I, already considers the management of species and ecosystems, as a way of ensuring the ecologically balanced environment.

\section{Complementary Law 140, of December 8, 2011}

According to the Brazilian legal system, a complementary law is above all others, only below the Federal Constitution. It is strict in its criteria but can still be changed. In 2011, the Complementary Law number 140 of December 8th, which establishes rules for cooperation between the Union, the States and the Federal District, regarding administrative actions to protect the environment, fight against pollution and forest preservation. Article 3 imposes on the Union, States and Municipalities the responsibility to: protect, defend and conserve the ecologically balanced environment by promoting decentralized, democratic and efficient management; ensure the balance of socioeconomic development with environmental protection; harmonize administrative policies and actions to avoid overlapping activities between federative entities, in order to avoid conflicts of attributions and ensure efficient administrative action; ensure the uniformity of environmental policy throughout the country, respecting regional peculiarities (BRASIL, 2011).

Therefore, it is recommended, in article 3, a decentralized management, the guarantee of socioeconomic development, the harmonization of actions to avoid overlapping function and respect for regional peculiarities. This article deserves special mention regarding the function of "non-overlapping of functions" between the national, state and municipal executive bodies.

Articles 7 and 8 assign as administrative action, respectively, the Union and the States, according to item XVII, the elaboration of the list of endangered species, through reports and technical-scientific studies, promoting activities that conserve these species in situ. This attribution was passed to the Botanical Garden of Rio de Janeiro, by means of article 7 of Decree 43 of the Ministry of the Environment (MMA), of 31 January 2014 (BRAZIL, 2014a). However, this assessment is currently carried out by the National Flora Center (CNCFlora), which evaluates the conservation status of the species and supports the periodic updating of the Official National List of Endangered Brazilian Flora Species (MESSINA, 2018), adopting the methodology of the International Union for Conservation of Nature (IUCN). Located in Rio de Janeiro, CNCFlora is a coordination within the Rio de Janeiro Botanical Garden, formed by a team of experts outside the Ministry of the Environment (MMA) staff.

Therefore, it must be understood that the law is not currently complied with. First, there are no technical and scientific reports that list the species, but the IUCN methodology is adopted. Secondly, a team of experts outside the board is handed over, in this case to CNCFlora, a fact not foreseen by law, to subsidize the list of endangered species.

\section{Law 12,651, of May 25, 2012}

The law Number 12,651, of May 25, 2012, establishes the current Forest Law, providing for the protection of native vegetation (BRAZIL, 2012). Its composition is the result of previously created laws. The six principles governed by the current Forest Law, in Article 1, show the importance of native vegetation, soil and water, before 
the State. Item II reaffirms the importance of agricultural activity and the role of forests in the country's economic growth. Item III governs government action for the protection and sustainable use of forests. Item VI discusses the creation and mobilization of economic incentives to promote the preservation and recovery of native vegetation and to promote the development of sustainable productive activities.

Thus, when analyzing the F.O.M. (Mixed Ombrophilous Forest), natural area of occurrence of Araucaria, how to insert it in the six principles of the Forest Law? Through item I with Brazil's sovereign commitment to preserve its forests? Or in item II, the strategic function of sustainability and economic growth? And finally, or in item VI, which refers to economic incentives to promote the preservation, recovery and development of sustainable productive activities? Well, in analyzing the principles of Law Number 12,651 of 2012, it is clear that they are intrinsically related to the FOM (Mixed Ombrophilous Forest) in all six principles. It is emphasized that the principles clearly show the strategic importance of forests, both in the preservation and economic development of the country, corroborating the possibility of obtaining economic incentives for the development of sustainable productive activities.

Article 3, item VII, discusses the understanding of sustainable management, in which the constitutional legislator foresees forest management as an economic technique that respects the mechanisms that sustain the ecosystem. Article 11 permits sustainable forest management and the exercise of agrosilvopastoral activities, observing good agronomic practices, and the conversion of new areas into slopes between $25^{\circ}$ and $45^{\circ}$, that is, restricted use areas within the Legal Reserve, is prohibited. It attributes this law to the legal reserve, in article 3, item III, delimited in article 12 (BRAZIL, 2012), the function of ensuring the sustainable economic use of natural resources of rural property. Now, what economic use can be assigned to flora, that promotes conservation, protects native flora, and maintains unchanged land use other than sustainable management?

Article 15, paragraph 2, within chapter IV, establishes the legal reserve area and guides the use of the surplus area (legal reserve area that exceeds the required by law). This is an innovation in Law number 12,651 of 2012 in which, finally, there is an economic advantage for those who have conserved native vegetation areas beyond what is stipulated by law. At first such surplus area may be negotiated through environmental easement and the Environmental Reserve Quota (CRA). Article 49, paragraph 1, authorizes that the area linked to the issuance of CRA (Environmental Reserve Quota) may be used in accordance with the Sustainable Forest Management Plan (PMFS). According to article 17, the legal reserve area must be conserved with native vegetation cover and sustainable forest management is authorized in paragraphs 1 and 2; and, in article 20, establishes the management modalities authorized in the legal reserve. Thus, the legislator acts to corroborate the low impact on management, and confirm the hypothesis that the economic management of timber conserves the forest by allowing the activity of CRA (Environmental Reserve Quota) and legal reserve to be authorized.

Article 22 establishes the obligation to authorize the competent agency to conduct commercial management in the legal reserve, provided that it does not decharacterize the vegetation cover, ensure species diversity and manage exotic species, so as to favor the regeneration of native species. Here, among the nearly 100 years of forest research in Brazil, there are several studies that prove that management does not decharacterize forest cover. (ROSOT, 2007; HESS et al., 2010; FANTINI e SIMINSKI, 2007; SANQUETTA e MATTEI, 2006; PINTO, 2009; NUTTO, 2001; ORELLANA et al., 2017).

Article 24 also provides for the application of Articles 21, 22 and 23 for forest management outside the legal reserve. Therefore, under Law number 12,651 of 2012, sustainable management is allowed in all Brazilian biomes, in the totality of the property (area of use, area of the legal reserve, area intended for CRA (Environmental Reserve Quota), except for the area of permanent preservation. Article 27, inserted within Chapter V (Vegetation Suppression for Alternative Land Use), governs that the suppression of vegetation harboring species of endangered flora or fauna, such as Araucaria, will depend on the adoption of measures compensatory and mitigating measures to ensure the conservation of the species. Article 31 presents the necessary technical criteria for the approval of the management plan, being unique to Brazilian biomes, again making no distinction to endangered species. It is important to highlight the items III and IV that refer to the cutting intensity and cutting cycle compatible with the carrying capacity of the forest.

Paragraphs 1, 2 and 3 of Article 35 govern the planted areas. The analysis of these paragraphs shows that the planting with Araucaria is free, regardless of prior authorization and must only be informed to the competent agency within a period of 1 (one) year. As well as, regardless of prior authorization, cutting of native planted species is allowed, provided that the cutting is previously declared for origin control purposes. The transport and storage of forest products and by-products from native species requires a license from the competent SISNAMA body, as provided for in article 36.

Chapter XII of this law discusses family farming on small farms (Article $3(\mathrm{~V})$ ). It must be noted that Article 52 allows the intervention and suppression of vegetation in APP and legal reserve for eventual activities or of low environmental impact, provided for in item X of article 3, thus encompassing, as per item $\mathrm{V}$ of article 3 
, point $\mathrm{j}$, sustainable community and family forest management. Such intervention will depend on a simple declaration to the competent environmental agency. Article 56 discusses the simplified procedure for environmental licensing of commercial PMFS on small farms. Article 57 allows the sustainable logging of the legal reserve on small farms for commercial purposes, with the simplified authorization of the competent environmental agency.

Articles 17, 31, 56, and 57 establish simplified procedures for the preparation, analysis, and approval of management plans on smallholdings or family rural tenure. Specifically analyzing the state of Paraná, there is an estimated $90 \%$ of the properties included as small properties or smallholdings (smaller than 4 rural modules), according to the Paraná Institute of Land, Cartography and Geology (ITCG, 2018). . Thus, as required by law, these could benefit from such simplified procedures.

In the complementary and final provisions of Law 12,651, Chapter XIV provides in Article 70 that the Government may prohibit the cutting of endangered species, delimiting areas included in the act. Thus, a specific species and area is delimited, and there is no possibility of generalized act for the entire national territory.

The articles contained in the Forest Law authorize the realization of forest management, including within the legal reserve areas. None of the articles distinguish between the authorization procedures of the PMFS in the various Brazilian biomes.

\section{Law 11,428, of December 22, 2006}

On December 22, 2006, Federal Law 11,428, also known as the "Atlantic Forest Law", is promulgated. It provides for the use and protection of the native vegetation of the Atlantic Forest Biome, and provides other measures (BRAZIL, 2006).

The integration of diverse ecosystems within the Atlantic Forest biome has generated much conflict and misunderstanding. Law number 11,428 comes from Decree 750 of 1993 (BRAZIL, 1993). It already prohibits the cutting and suppression of primary vegetation in the middle and advanced stages in the Atlantic Forest, according to article 1. But there is, in the 3rd paragraph, the most controversial, in which the Atlantic Forest is considered the forest formations and associated ecosystems inserted in the Atlantic Forest domain, with the respective delimitations established by the Vegetation Map of Brazil, IBGE (Brazilian Institute of Geography and Statistics) 1988. Thus, before the Decree 750 of 1993, in the limits of the Atlantic Forest, according to IBGE (Brazilian Institute of Geography and Statistics) map, the various forest formations will be treated as Atlantic Forest. Therefore, fragments outside this limit would not be part of this Decree.

Federal Law 11,428 provides, in article 2, that integrate into the Atlantic Forest Biome, for the purposes of the law, native forest formations and associated ecosystems according to the boundaries established by the Brazilian Institute of Geography and Statistics (IBGE): Dense Ombrophilous Forest; Mixed Ombrophilous Forest, also called Araucaria Forest; Open Ombrophilous Forest; Semideciduous Seasonal Forest; and Seasonal Deciduous Forest, as well as the mangroves, restingas vegetation, altitude fields, inland swamps and northeastern forests. Therefore, it is an administrative effect. There is no change in maps.

Furthermore, the sole paragraph of article 2 governs that, according to the coverage area defined in the caput, its use and conservation shall be regulated by this law the remnants of native vegetation in the primary stage and in the early, middle and advanced stages of regeneration. Therefore, the consolidated areas - agricultural, plantation and urban - are governed exclusively by the new Forest Law. Areas reforested with pine and araucaria, urban vegetation, isolated trees are not part of Law 11,428 of 2006.

It is established in Article 7 that the protection and use of the Atlantic Forest Biome will be done under four conditions. Point II stands out, which allows the protection and use by stimulating research, diffusion of sustainable vegetation management technology and public awareness about the need for ecosystem recovery and maintenance.

Cutting and suppression of primary vegetation or in the middle and advanced stages of biome regeneration, according to the provisions of this law (BRAZIL, 2006), article 11, are forbidden when sheltering endangered species of wild flora and fauna in the national territory., or at the state level, as declared by the Union or the States, and the intervention or the installment may endanger the survival of these species.

And also in article 11, sole paragraph, where there is a direct inference to areas that house endangered species of wild flora and fauna, that the Executive Power will encourage and support the actions and owners of areas that are maintaining or sustaining their survival species (BRAZIL, 2006). This paragraph is closely related to this theme. According to Braz and Mattos (2015) natural forest management is the only land use that guarantees the maintenance of the forest. The number of remaining trees reaches $88 \%$.

The use, cutting and suppression of primary and secondary vegetation at an advanced stage will only be authorized in cases of public utility. In the middle stage, they will be authorized in cases of public utility and social

FLORESTA, Curitiba, PR, v. 50, n. 1, p. 971 - 982, jan/mar 2020

Eisfeld, R. L. et.al.

ISSN eletrônico 1982-4688 
interest, according to articles 14 and 17 of this law (BRAZIL, 2006). Article 19 allows the eventual cutting of primary or secondary vegetation in the middle and advanced stages of regeneration of the Atlantic Forest Biome, for the purpose of preservation practices and scientific research, duly regulated by the National Environment Council and authorized by the agency. SISNAMA. Article 20 allows the exceptional cutting of primary vegetation for scientific research activities and preservation practices. Article 23 allows the cutting of secondary vegetation, in the middle stage of regeneration, for scientific research and necessary for the survival of small farmers, as per items I and III.

Article 28 provides for the cutting and management, when authorized by the competent state agency, of native pioneer tree species in forest fragments in the middle stage of regeneration, in which their presence is greater than $60 \%$ (sixty percent) in relation to the other species. In this case, the legislator does not clarify the term "presence", which could refer to various results from the forest, such as abundance, dominance, frequency, importance value index, or even volume. If the term refers to the number of individuals, rare are the species with economic potential that fall into this article. Only the bracatinga (Mimosa scabrella Benth.).

It establishes, by Article 33, that the Government will stimulate, with economic incentives, the protection and sustainable use of the Atlantic Forest Biome. Including, in item II, which will be observed, as to economic incentives, the existence of endangered species of fauna and flora. Article 46 governs that the competent bodies shall stimulate technical and scientific studies aimed at the conservation and rational management of the Atlantic Forest Biome and its biodiversity. Thus, it clearly corroborates that there is no prohibition on management in Law 11.128 of 2006, but an incentive, as a practice of conservation and improvement of the forest. There is, however, a clear ban on logging and suppression, but not on sustainable forest management.

The analysis of Law number 11,428 of December 22, 2006 shows, at first, a rather controversial point. It explicitly provides for the Law on the use and protection of native vegetation of the Atlantic Forest Biome. However, there are few articles about the use of the biome.

\section{Decree 6,660 of November 21, 2008}

On November 21, 2008, Decree 6,660 is published, which regulates provisions of Law number 11,428, providing for the use and protection of the native vegetation of the Atlantic Forest Biome (BRAZIL, 2008). Decree is a rule that complements, regulates a law, down to the details, addressing the special aspects necessary for the practical application of legislation, whose competence for dispatch is the Chief Executive.

Article 2 of this decree, referred to in Article 9 of Law number 11,428 of 2006, rules the withdrawal of no more than $15 \mathrm{~m}^{3}$ annually for domestic use; the removal not exceeding $20 \mathrm{~m}^{3}$ every 3 years for use in construction and improvements. Paragraph 5 prohibits exploitation of species included in the official list of endangered species of Brazilian flora.

Chapter IV of Decree 6,660 (BRAZIL, 2008) deals with the planting and reforestation of native species, which are independent of authorization from the competent environmental agency (article 12). Article 12 allows planting and reforestation for sustainable agroforestry management activities to be carried out in consortium with exotic, forest or agricultural species.

Article 13 authorizes the planting of native species in secondary tree vegetation in the middle and advanced stages of regeneration for the purpose of production and marketing. However, paragraph 2, paragraph I, prohibits the cutting of native species that are part of the official list of threatened species, and prohibits the cutting of primary vegetation and tree individuals in the advanced stage of regeneration in the other sections. It is therefore a completely incoherent article. The article authorizes the planting of species for commercialization, but item I of paragraph 2 restricts its future cut, making it contradictory.

Article 14 provides that harvesting or exploitation of demonstrably planted native species shall only be permitted if the planting or reforestation has been previously registered with the environmental agency, within a maximum period of 60 days after planting. Paragraph 1 stipulates that the register of native species planted or reforested will be created. Such registration has not been created so far. At the time of cutting (article 15) must be notified to the environmental agency containing information of the registration number, volume by species, location of the area with geographical coordinates. The term "notification" refers to an immediate, spontaneous and automatic authorization.

Owners of native planted areas who have not previously registered must notify the competent agency with owner information, property registration, volume and quantity of trees, planting date, geographical location and technical report, signed by a qualified professional, certifying that when dealing with a plantation in the case of endangered species, as per Article 16. The sole paragraph governs that for the purposes of Articles 15 and 16, for endangered species, the authorization to carry shall depend on the analysis of the information provided and prior field survey. Article 18 is exempt from providing the information described in Articles 15 and 16 to producers

FLORESTA, Curitiba, PR, v. 50, n. 1, p. 971 - 982, jan/mar 2020 
who harvest up to a maximum of $20 \mathrm{~m}^{3}$ every three years for use or consumption on the property for no commercial purpose.

Chapter XII describes the suppression of endangered species. According to article 39, in order to have the authorization for the cut, there must be a technical opinion of the environmental agency certifying the absence of a technical and locational alternative. It must also be ensured that the impacts of logging will be adequately mitigated and will not aggravate the risk to in situ survival of the species (BRAZIL, 2006).

At the end of the decree, Chapter XIV establishes the municipal plan for the conservation and recovery of the Atlantic Forest. Article 43 states that such a plan shall contain: diagnosis of native vegetation containing remnant mapping at a scale of 1: 50,000 or greater; indication of the main vectors of deforestation or destruction of native vegetation; indication of priority areas for conservation and restoration of native vegetation; IV indications of preventive actions to deforestation or destruction of native vegetation and conservation and sustainable use of the Atlantic Forest in the municipality.

Thus, more than 10 years after the publication of Decree 6,660, there is no biome conservation and recovery plan. There is no official mapping of the remnants, despite all existing technology. There are recent satellite images of the RapidEye satellite, which covers the entire territorial extension of Brazil, acquired for the preparation of the Rural Environmental Registry (CAR). There is a pertinent question: If all the tools are available to make a good mapping of the remnants, why not publish official and recent data?

\section{CONAMA (National Environment Council) Resolution, Number 278, of May 24, 2001}

In May 2001, CONAMA (National Environment Council) resolved to determine to IBAMA (Brazilian Institute of Environment and Renewable Natural Resources) the suspension of authorizations granted by its own act or by delegations to other SISMANA organs, for the cutting and exploitation of endangered species, included in the official list of that organism (PIRES, 2006), according to Article 1 of this resolution. Since the publication of this resolution, any commercial use of these species has been forbidden, with the suspension of forest management plans in execution (PIRES, 2006).

Pires (2006) highlights the concern of CONAMA (National Environment Council) with Resolution number 278 of May 24, 2001 with very questionable criteria. According to the author, there is an increase in legal uncertainty and makes it difficult to legitimize the conservation process of the Atlantic Forest biome. Also in article 1, sole paragraph, CONAMA (National Environment Council) itself stipulates a period of one year, extendable by one more to set the technical and scientific criteria for each species. More than 17 years later, such criteria have not been established for any of the species on the official threatened list.

Since the issuance of this regulation in 2001, there has been no management of Araucaria. Now the question is: what is the positive effect of this? What are the concrete benefits that have been obtained in this period for the species?

\section{MMA decree 43 of January $31^{\text {st }}, 2014$}

The Ministry of the Environment (MMA) Decree, number 43, of 31 and January 2014, preceding Decree 443, which lists endangered species, aimed to establish the national conservation program for endangered species, called what is meant by threat, describe the procedures for framing the species, among other objectives.

In Article 1, the National Program for the Conservation of Endangered Species is instituted, with the purpose of adopting prevention, conservation, management and management actions in order to reduce the risk of species extinction (BRAZIL, 2014a). It is interesting to highlight the legislator's position when framing management as a possible action to reduce the threat of the species.

Article 2 defines threatened species as those whose populations and / or habitats are rapidly disappearing in order to put them at risk of becoming extinct. To this end, the extinction risk assessment method is adopted in accordance with the definitions and criteria of the International Union for Conservation of Nature (IUCN). Ten different groups are stipulated, among them: a) Extinct (EX), b) Extinct in Nature (EW), c) Critically Endangered $(\mathrm{CR}), \mathrm{d})$ Endangered (EN), and) Vulnerable (VU). The Araucaria species, object of this study, was classified in the EN (endangered) category which, according to Decree 43 (BRAZIL, 2014a), is considered that the species is facing a very high risk of extinction in the wild.

The process of defining endangered species, according to article 4, must go through the following steps: I - creation and management of databases and information systems aimed at supporting extinction risk assessments and the planning of conservation actions; II - conducting an assessment of the conservation status of species to fit them into the threat of extinction categories, based on existing scientific information; III - publication of the Official National List of Endangered Species; IV - elaboration of National Action Plans for the Conservation of

FLORESTA, Curitiba, PR, v. 50, n. 1, p. 971 - 982, jan/mar 2020

Eisfeld, R. L. et.al.

ISSN eletrônico 1982-4688 
Endangered Species-PAN; and V - monitoring the implementation of the NAPs and the conservation status of threatened species (BRAZIL, 2014a).

The Pro-Species Program, as governed by article 5, will be coordinated by the Ministry of Environment and among its many objectives, the following must be coordinated: the elaboration of the National Action Plan (PAN) for the conservation of endangered species; promote, in liaison with the Ministry of Science, Technology and Innovation, studies and strategies aimed at restoring the conservation status of threatened species, as well as associated habitats and ecosystems; coordinate the integration of information on endangered species to enable data management and documentation and the implementation and monitoring of planned actions. Although Decree 43 was issued in 2014, there are few published PANs of flora. For arboreal species only, the PAN prepared for Wilson's Faveiro (Dimorphandra wilsonii Rizzini).

Article 7 of the Decree establishes that conservation status assessments must contain at least information on geographic distribution, conservation status and main threat factors. Evaluations are technical and scientific in character and must consider the following criteria: population size and information on past and / or projected fragmentation, fluctuations or decline; extent of geographic distribution, decline or fluctuations; threats affecting the species; and existing conservation measures.

\section{MMA (Ministry of the Environment) - decree number 443, of December 17 ${ }^{\text {th }}, 2014$}

In 2013, the Rio de Janeiro Botanical Garden published the Red Book of Flora of Brazil (MARTINELLI and MORAES, 2013). This book served as the basis for updating the official list of endangered Brazilian flora species, published by the Ministry of the Environment, through Decree 443 of December 17, 2014 (BRAZIL, 2014b).

This Decree prohibited the management of the species included in the list, except those categorized as vulnerable, according to articles 2 and 3. Such measure made any economic activity in the state of Paraná unfeasible, considering that practically all commercial species are included in the list: Araucaria angustifolia: endangered, Ocotea porosa: endangered, Ocotea catharinensis: vulnerable, Cedrela fissilis: vulnerável, Euterpe edulis: vulnerable, Tabebuia cassinoides: endangered, among others.

Described in Article 2, the species listed in the first four categories (EW, CR, EN and VU) are fully protected, including the prohibition of collection, cutting, transportation, storage, handling, processing and marketing, among others. Article 3 allows forest management for species classified in the VU category, meeting the criteria established in the article (BRASIL, 2014b).

According to Martinelli and Moraes (2013), the inclusion of Araucaria in the list is justified by: severe population reduction over the last years $(>80 \%)$, deforestation $(>80 \%)$, logging, construction of hydroelectric plants in the Southern Region and presence of exotic animals (wild boars and cattle).

\section{DISCUSSION}

The problem involving the Araucaria species is remarkably delicate. They are meetings, councils, forums, seminars, congresses; Finally, infinite and disconnected discussions that effectively do not revert to the increase of planted area or regeneration of the species in the field. There is a current framework of preservation of native areas, under the law; and a stabilization of araucaria forest plantations in the State (IBÁ, 2017), often caused by the range of regulations that make investors approach the exotic and move away from the native ones. But can the constant instrument of the force of law really help in the conservation of a species? The very framing of the species, as critically endangered, already implies the answer to this question.

The challenges are diverse to solve the threat of species extinction. However, Brazil bets a lot on solving non-legal problems, becoming law. The country, despite being new in the legal context, has a huge inflation of laws. It solves economic problems by making law; rampant inflation of the 1970s and 1980s, making law; traffic violence, making law; and finally, the issue of araucaria, also making law. The law is only an instrument of policy. It is wrong to bet solely on the legal mechanism, given so many other existing mechanisms. Very little bets on education, culture and mindset change. The issue is never just legal, it is also cultural, political, economic, it is justice, and ultimately it is law.

The strategy of using force of law to conserve natural resources, as cited by Fantini and Siminski (2007), has been a failure. The insistence on this strategy, however, is possibly due to the fact that this is still the easy way out compared to the complex task of promoting conservation through the rational use of forest resources. This, however, is the strategy that promises long-term success.

The withdrawal of the economic function of species is a big mistake in the path of conservation. Initially, this fact unfolded with the creation of numerous obstacles, initiated in Decree 750 of 1993 (BRAZIL, 1993), such 
that the species could no longer be operated, as they should be and began to be operated in a predatory manner. But in agreeing that the species can be conserved by use, why not use araucaria? Is the legislation really a deterrent to the use of native species under forest management or cutting of planted individuals.

Analyzing all the main legal rules regarding Araucaria, as discussed in this article, it is concluded that: the use is still possible from the perspective of current environmental legislation. The current legislation in force under the Forest Law (Law 12,651 of 2012), Atlantic Forest Law (Law number 11,428 of 2006) and its Regulatory Decree (Decree, number 6,660 of 2008) do not prohibit the management and cutting of plantations.

CONAMA (National Environment Council) Resolution number 278 of 2001 that suspended authorizations for cutting or exploitation of endangered species, which led to the suspension of management plans in the state of Paraná, is expired and must be revoked. First, the terms "logging or logging" cannot be confused with forest management. In addition, its term was one year, which could be extended for a further period, until CONAMA (National Environment Council) established technical and scientific criteria for each species, which, to date, have not been elaborated.

Explicitly, MMA (Ministry of the Environment) Decree number 443 of 2014 prohibits the management of fully protected species on the endangered species list. Such Decree makes management plans unfeasible in the State of Paraná, since the main commercial species are included in this federal list. Now is the new question "Is forest management to blame for the extinction of these species? Will the ban on forest management ensure their conservation?". Now, it is worth taking here the concepts of forest management defined in the Brazilian legislation:

Sustainable management: management of natural vegetation to obtain economic, social and environmental
benefits, respecting the support mechanisms of the ecosystem under management and considering,
cumulatively or alternatively, the use of multiple wood species or not, multiple flora products and by-
products, as well as the use of other goods and services (BRASIL, 2012b). Management: any and all
procedures aimed at ensuring the conservation of biological diversity and ecosystems (BRAZIL, 2000).

The controversial of Decree 443 with the Forest Law and Law Number 9,985 of 2000 (SNUC - National System of Conservation Units) is exemplified. If management is a conservation-safe procedure, what is the real reason for being suspended for endangered species? On the contrary, it should be encouraged and funded.

In addition, there are two aggravating factors inherent to Decree 443: i) it conflicts with the Brazilian Forest Law by withdrawing the right, in this case forest management, not established by Law number 12,651 of 2012. It is a generalized act, which is not foreseen in a decree. There is not a single administrative act that overrides the law; ii) does not comply with Complementary Law 140, which establishes reports and technical-scientific studies for framing the species on the list. The ban on the use of a species cannot come from an Decree. It is a legally fragile device. The only way to create or extinguish rights is through the Law. In this case, Decree number 443 of 2014, innovates by prohibiting the management of threatened species.

Regarding the listing of the species, it is unquestionable to reduce the areas of occurrence of all forest formations present in the State of Paraná. But what cannot be admitted is the omission of official data on area and population, matters of state obligation; the first under IBGE (Brazilian Institute of Geography and Statistics) competence and the second, via National Forest Inventory, provided for in article 71 of Law number 12.651 of 2012. Only through official data, could an adequate justification of the classification of species be given.

Decree 443 of 2014 also fails to comply with Decree 43 (BRAZIL. Ministry of the Environment, 2014a) by editing a list without complying with the steps required in article 4 (I - database, II - conservation status assessment, III - publication IV - NAP elaboration, V - NAP monitoring and conservation status). The remaining area base in the different Brazilian biomes, attributed to IBGE (Brazilian Institute of Geography and Statistics), is nonexistent. Unofficial data is adopted to support the areas. There is no published publication of PAN for FOM (Mixed Ombrophilous Forest) species, especially the Araucaria species. Therefore, it does not fulfill the steps required in Article 5. It is noteworthy that Decree 43 is precedent to 443 and was not revoked.

\section{CONCLUSIONS}

The study concludes that:

- The 1988 Brazilian Constitution, innovative in its discussion of the environment, in its Article 225, item I, already provides for the management of species and ecosystems as a way of ensuring an ecologically balanced environment;

- There is no compliance with Complementary Law 140 which, by legal order, is above all laws. Article 8, clause XVII, is infringed by the fact that there are no technical and scientific reports that put the species

FLORESTA, Curitiba, PR, v. 50, n. 1, p. 971 - 982, jan/mar 2020

Eisfeld, R. L. etal.

ISSN eletrônico 1982-4688 
on the threatened list and for being carried out by specialists outside the staff, a fact not provided for by law;

- In Law 12,651 of 2012, article 3, the constitutional legislator provides for management as an economic technique that respects ecosystem support mechanisms. Articles 21, 22, 23 and 24 allow sustainable management in all Brazilian biomes, in the totality of the property, including CRA (Environmental Reserve Quota) areas, except for the permanent preservation area. Article 35 allows, regardless of prior authorization, the cutting of native planted species;

- Attention is given to the work of the Sole Paragraph of Article 2 of Law 11,428 of 2006, which only governs the remnants of native vegetation in the primary and secondary stages. Therefore, the consolidated areas - agricultural, plantation and urban - are governed exclusively by the new Forest Law;

- Article 11, in the Sole Paragraph of Law 11,428 of 2006, is infringed, attributing to the Executive Power the promotion and support to the actions and the owners of areas that are maintaining or sustaining the survival of these species. Such mandate is also attributed in article 46. It explicitly provides for the Law on the use and protection of native vegetation of the Atlantic Forest Biome. However, the articles of this law on the use of the biome are limited;

- CONAMA (National Environment Council) Resolution number 278 of 2001 temporarily suspended the cutting and exploitation of endangered species. It provides, by means of Article 1, sole paragraph, for a period of one year, which may be extended by one more year to lay down the technical and scientific criteria for each species. Thus, the resolution is infringed: i) time-exceeded; ii) technical criteria not elaborated;

- $\quad$ MMA (Ministry of the Environment) Decree number 43 of 2014 establishes the National Program for the Conservation of Endangered Species, with the objective of adopting prevention, conservation, management and management actions. It is established, through article 4, the stages of inclusion of the species as threatened and, via article 7, the constant data to establish the conservation status assessments. The Decree is infringed by editing the list of species without complying with the steps contained in this Decree;

- Decree 443 is illegal in the following respects: i) it clashes with the Brazilian Forest Law by removing right, in this case forest management, not established by Law number 12,651 of 2012. It is a widespread act, which is not foreseen in a decree; ii) does not comply with Complementary Law 140 which establishes reports and technical-scientific studies for classification of the species on the list; iii) does not comply with Decree 43 by editing a list without complying with the steps required in article 4;

- Regarding the analysis of the regulations regarding the Araucaria species, its commercial use is only one: there is no law prohibiting the use, through management of the natural forest and planting; yes there are Decrees and resolutions. Rules a certain ignorance between the parties. Those who find themselves in the messianic right to forbid the cutting of the species subscribe to Decrees and resolutions. And who is entitled to cut, is unaware of the legislation. Non-commercial use of the species, via management or planting, is not a legal problem. There is a political bias; it is a political option of the state;

- The state has invested in a punishing, sanctioning and unsuccessful system. It has not entered a phase that rewards, promotes and stimulates. There is a transition between legislation that has run out, created a divorce between man and nature; between the producer and the araucaria. The system in which the state looks at everything, sees everything, prohibits, restricts, fines, ... has failed, it no longer exists;

- Araucaria suffered consequences from extremes: against or for. To be an environmentalist for decades, with rare exceptions, was to be against everything. The other was to be for everything, chainsaw. Also developed in the minds of the producers a belief, somewhat rooted, that in Araucaria can not move. The law prohibits the IBAMA (Brazilian Institute of Environment and Renewable Natural Resources) fine, the police arrest. The Araucaria is untouchable! It is a prejudice! Legal improvement must come through a Forest Development Policy, making Araucaria enter the production cycle. The first effort, and what works best, is to educate, to form a new culture, to arouse consciousness; This is the great role of the state. 


\section{REFERENCES}

BRASIL. MINISTÉRIO DA AGRICULTURA. INSTITUTO BRASILEIRO DE DESENVOLVIMENTO FLORESTAL. Portaria Normativa DC no 20, de 27 de setembro de 1976. Proibe o abate de pinheiros adultos (Araucaria angustifolia), portadores de pinhas, nos meses de abril, maio e junho. Brasília, DF, 27 de setembro de 1976.

BRASIL. Constituição (1988). Constituição: República Federativa do Brasil. Brasília, DF: Senado Federal, 1988.

BRASIL. Decreto no 750, de 10 de fevereiro de 1993. Dispõe sobre o corte, a exploração e a supressão de vegetação primária ou nos estágios avançado e médio de regeneração da Mata Atlântica, e dá outras providências. Diário Oficial [da] República Federativa do Brasil, Poder Executivo, Brasília, DF, 11 de fevereiro de 1993.

BRASIL. Lei No 9.985, de 18 de julho de 2000. Regulamenta o art. 225, § 1o, incisos I, II, III e VII da Constituição Federal, institui o Sistema Nacional de Unidades de Conservação da Natureza e dá outras providências. Diário Oficial [da] República Federativa do Brasil, Poder Executivo, Brasília, DF, 2000.

BRASIL. Lei $\mathbf{n}^{0}$ 11.428, de 22 de dezembro de 2006. Dispõe sobre a utilização e proteção da vegetação nativa do Bioma Mata Atlântica, e dá outras providências.: Diário Oficial [da] República Federativa do Brasil, Poder Executivo, Brasília, DF, 26 de dezembro de 2006.

BRASIL. Decreto $n^{0}$ 6.660, de 21 de novembro de 2008. Regulamenta dispositivos da Lei no 11.428, de 22 de dezembro de 2006, que dispõe sobre a utilização e proteção da vegetação nativa do Bioma Mata Atlântica. Diário Oficial [da] República Federativa do Brasil, Poder Executivo, Brasília, DF, 24 de novembro de 2008.

BRASIL. Lei complementar $\mathbf{n}^{\mathbf{0}}$ 140, de 8 de dezembro de 2011. Fixa normas, nos termos dos incisos III, VI e VII do caput e do parág. único do art. 23 da Constituição Federal, para a cooperação entre a União, os Estados, o Distrito Federal e os Municípios nas ações administrativas decorrentes do exercício da: competência. Diário Oficial [da] República Federativa do Brasil, Poder Executivo, Brasília, DF, 8 de dezembro de 2011.

BRASIL. Lei Federal 12.651 de 25 de maio de 2012. Dispõe sobre a proteção da vegetação nativa; altera as Leis nos 6.938, de 31 de agosto de 1981; e dá outras providências: Diário Oficial [da] República Federativa do Brasil, Poder Executivo, Brasília, DF, 28 de maio de 2012.

BRASIL. MINISTÉRIO DO MEIO AMBIENTE. Portaria MMA No 43, de 31 de janeiro de 2014. Institui o Programa Nacional de Conservação das Espécies Ameaçadas de Extinção - Pró-Espécies. Brasília, 2014a.

BRASIL. MINISTÉRIO DO MEIO AMBIENTE. Portaria MMA No 443, de 17 de dezembro de 2014. Lista Nacional Oficial de Espécies da Flora Ameaçadas de Extinção. Brasília, 2014b.

BRASIL. MINISTÉRIO DO MEIO AMBIENTE. CONSELHO NACIONAL DO MEIO AMBIENTE. Resolução $n^{0}$ 278, de 24 de maio de 2001. Dispõe sobre o corte e a exploração de espécies ameaçadas de extinção da flora da Mata Atlântica. Diário Oficial [da] República Federativa do Brasil, 138-E, Poder Executivo, Brasília, 18 de julho de 2001, Seção 1, páginas 51-52., 2001.

BRAZ, E. M.; MATTOS, P. P. Management of production forests in Amazonian region: myths and truths. Nativa: Pesquisas Agrárias e Ambientais, v. 3(4), p. 292-295, 2015. Cuiabá, MT.

FANTINI, A. C.; SIMINSKI, A. De Agricultor à Agricultor Silvicultor: Um Novo Paradigma para a Conservação e uso dos recursos florestais no Brasil. Revista Agropecuária Catarinense, v. 20, p. 16-18, 2007. Florianópolis.

FUPEF - FUNDAÇÃO DE PESQUISAS FLORESTAIS DO PARANÁ. A Floresta com Araucária no Paraná. $1^{\circ}$ ed. Curitiba, PR: Conservação do Bioma Floresta com Araucária: Diagnóstico dos Remanescentes Florestais. Projeto de Conservação e Utilização Sustentável da Diversidade Biológica Brasileira - PROBIO. Ministério do Meio Ambiente, 2001.

HESS, A. F.; CALGAROTTO, A. R.; PINHEIRO, R.; WANGINIAK, T. C. R. Proposta de manejo de Araucaria angustifolia utilizando o quociente de Liocourt e análise de incremento, em propriedade rural no Município de Lages, SC. Pesquisa Florestal Brasileira, v. 30(64), p. 337-345, 2010.

IBÁ. INDUSTRIA BRASILEIRA DE ÁRVORES. Relatório 2017. Relaório Anual, Brasília, DF. p.80, 2017.

MARTINELLI, G, MORAES, M. A. Livro vermelho da flora do Brasil. Rio de Janeiro: Instituto de Pesquisas

FLORESTA, Curitiba, PR, v. 50, n. 1, p. 971 - 982, jan/mar 2020

Eisfeld, R. L. et.al.

ISSN eletrônico 1982-4688

DOI: $10.5380 /$ rf.v50 i1.60023 
Jardim Botânico do Rio de Janeiro. 1ª Edição, 2013.

MESSINA, T. CNC Flora. Projeto Lista Vermelha da Flora. Disponível em: <http://dipeq.jbrj.gov.br/conservacao/cnc-flora/>. Acesso em: 24/5/2018.

NUTTO, L. Manejo do crescimento diamétrico de Araucaria angustifolia (Bert.) O. Ktze. baseado na árvore individual. Ciência Florestal, v. 11-n. 2, p. 9-25, 2001.

ODUM, E. P. Ecologia [Ecologia Animal, Ecologia Vegetal; Ecologia Aquática; Meio Ambiente]. $3^{\mathrm{a}}$ Edição. ed. 1977.

ORELlANA, E.; FIGUEIREDO FILHO, A.; PÉLlICO NETTO, S.; VANCLAY, J. K. A distance-independent individual-tree growth model to simulate management regimes in native Araucaria forests. Journal of Forest Research, v. 22, n. 1, p. 30-35, 2017. Disponível em: 〈https://doi.org/10.1080/13416979.2016.1258961>. .

PINTO, G. R. M. A revalorização como forma de garantir a perpetuação do pinheiro brasileiro (Araucaria angustifolia) e floresta de araucárias. Disponível em: <http://www.sct.embrapa.br/cdagro/tema05/05tema04.pdf>. Acesso em: 14/2/2018.

PIRES, P. T. L. Aspectos legais. In: SANQUETTA, C. R., MATTEI, E. Perspectivas de recuperação e manejo sustentável das florestas de araucária. p.53-104. Curitiba, Multi-Graphic Gráfica, 2006.

ROSOT, M. A. D. Manejo florestal de uso múltiplo: uma alternativa contra a extinção da Floresta com Araucária? Pesquisa Florestal Brasileira, v. 55, p. 75-85. Colombo, jul/dez, 2007.

SANQUETTA, C. R., MATTEI, E. Perspectivas de recuperação e manejo sustentável das florestas de araucária. $1^{\circ}$ ed. Curitiba, PR: Multi-Graphic Gráfica, 2006. 